Reprod. Nutr. Dévelop., 1981, 21 (1), 59-68.

\title{
Annual plasma testosterone cycle and ejaculatory ability in the laboratory-housed crab-eating macaque (Macaca fascicularis)
}

\author{
par D. C. DANG, Nicole MEUSY-DESSOLLE * \\ Laboratoire d'Anatomie, U.E.R. Biomédicale, \\ 45, rue des Saints-Pères, 75270 Paris Cedex \\ * Laboratoire de Physiologie de la Reproduction des Vertébrés, Université Paris VI \\ and I.N.R.A., 78350 Jouy-en-josos, France
}

Summary. Six fertile and healthy adult Macaca fascicularis males were studied. Radioimmunological assay of the plasma testosterone, sampled without anesthesia in the afternoon at the beginning of each month, showed an annual hormone cycle with a maximum $(16.7 \pm 1.1 \mathrm{ng} / \mathrm{ml})$ in the fall and a minimum $(9.5 \pm 0.9 \mathrm{ng} / \mathrm{ml})$ in the spring (fig. 1$)$. Using the ratio : number of ejaculations/number of trials, the ejaculatory ability of these animals (fig. 2) was estimated for $10 \mathrm{~min}$ in the presence of females between days 12 and 15 of their menstrual cycle. This ability showed no cyclic variation during the year.

Comparing the annual variation of testosterone levels in macaque males (Macaca mulatta, Macaca arctoides, Macaca nemestrina, Macaca fascicularis) and man, we found that, except for Macaca arctoides and Macaca nemestrina, the maximal simian levels always coincided with autumn and the minimal levels with spring in spite of the different rearing environments. (table 2).

After studying ejaculatory ability and plasma festosterone level in the intact macaque throughout the year and comparing it to the results obtained by Resko and Phoenix (1972), Phoenix ef al. (1973) and Michael and Wilson $(1974,1975)$ studying castrated males, we believe that above a minimal level, variation in the plasma testosterone level does not affect male sexual behavior, at least as far as ejaculatory ability is concerned. Moreover, during this study we noted that above a maximal plasma testosterone level, varying with the season, the ejaculation rate may be depressed (fig. 3 ).

\section{Introduction.}

A mating season has been observed in macaques (non-human primates) living in their natural habitat or in an outdoor enclosure : Macaca mulatta (Conoway and Koford, 1964 ; Lancaster and Lee, 1965 ; Neuville, 1968 ; Vandenbergh and Vessey, 1968), Macaca fuscata (Tokuda, 1962 ; Hanby, Robertson and Phoenix, 1971 ; Eaton, 1972), Macaca sylvana (McRoberts and McRoberts, 1966), Macaca fascicularis (Gauquelin, 1968). However, there is no evidence of a restricted birth season in other macaques 
raised in an outdoor enclosure (Macaca arctoides : Estrada and Estrada, 1976 ; Macaca nigra : Dixson, 1977), for births occur throughout the year.

When raised under stable photoperiod, temperature, humidity and diet, rhesus (Macaca mulatta) and Japanese (Macaca fuscata) macaques retain their seasonal breeding habits (Valerio, Pallota and Courtney, 1969 ; Nomura and Ohsawa, 1975 ; Aso et al., 1977) characterized by a period of amenorrhea in the female (Riesen, Meyer and Wolf, 1971) and a decline in male sexual activity (Michael and Keverne, 1971) concomitant with a decreasing blood testosterone level (Plant et al., 1974 ; Robinson et al., 1975 ; Gordon, Rose and Bernstein, 1976 ; Michael and Bonsall, 1977).

Conversely, crab-eating macaques (Macaca fascicularis) in our laboratory, although raised in natural photoperiod at a constant temperature (Dang, 1977), reproduce regularly all year long, and ejaculation almost always accompanies copuIation when the males have access to the females between days 12 to 15 of their menstrual cycle. We thus wished to determine if the male plasma testosterone level was stable throughout the year.

\section{Material and methods.}

Six fertile, healthy adult males imported from southeast Asia in 1972 were used in this study; they were raised in the conditions previously described (Dang, 1977) : individual cages, natural photoperiod, relatively constant temperature (24 to $28^{\circ} \mathrm{C}$ ) and hygrometry, monkey chow occasionally supplemented with fruits and vegetables.

Blood samples were taken by puncture of the saphena or radial vein on days when there was no copulation; the animal was not anesthetized but restrained in a holding cage with a movable side. All the animals had been accustomed to blood sampling for a whole year before the experiment began. The blood samples, taken in the afternoon between $2: 30$ and 5:30 p. m. at the beginning of every month for one year, were heparinized and centrifuged immediately. The plasma was stored at $-20^{\circ} \mathrm{C}$ until assay. The next year, serial samples were taken from 4 of the 6 males every hour between 2:30 and 5:30 p. m. on one day in March and November to determine if the androgen level had changed during the afternoon.

Plasma testosterone was assayed by a radioimmunological method described elsewhere (Dang and Meusy-Dessolle, 1979). Assay sensitivity was about 5 pg/tube. Inter-assay variabilities were 7.9 p. 100 and 2.5 p. 100 for $6.8 \mathrm{ng} / \mathrm{ml}$ and $15,6 \mathrm{ng} / \mathrm{ml}$ respectively. Intra-variabilities were 6.2 p. 100 for $2.2 \mathrm{ng} / \mathrm{ml}$ and 2.1 p. 100 for $15.8 \mathrm{ng} /$ $\mathrm{ml}$. Mean «water blank» was $0.006 \mathrm{ng} / \mathrm{ml}$. Mean recovery after extraction was $95 \pm 0.9$ p. 100.

Male ejaculatory ability was studied monthly in the presence of fertile adult females between days 12 and 15 of the menstrual cycle and determined during a 10-min period by the ratio : number of ejaculations/number of mating tests. The male was tested three times a day at minimum 2-hr intervals, each time with a different female. Less than 31 mating tests per month were practised on each male.

The statistical significance of the between-month differences was evaluated using Student's t-test. 


\section{Results.}

The plasma testosterone pattern in each animal (a) and the mean (b) of the 6 animals sampled over a 1-year period are shown in figure 1. All except male $M N$ (heavy line) showed a yearly androgen cycle : the testosterone level was maximal in September and October $(16.7 \pm 1.1 \mathrm{ng} / \mathrm{ml})$ and minimal $(9.5 \pm 0.9 \mathrm{ng} / \mathrm{ml})$ in the spring (March, April, May, June). It rose in April but there was no significant difference between March and Ápril.

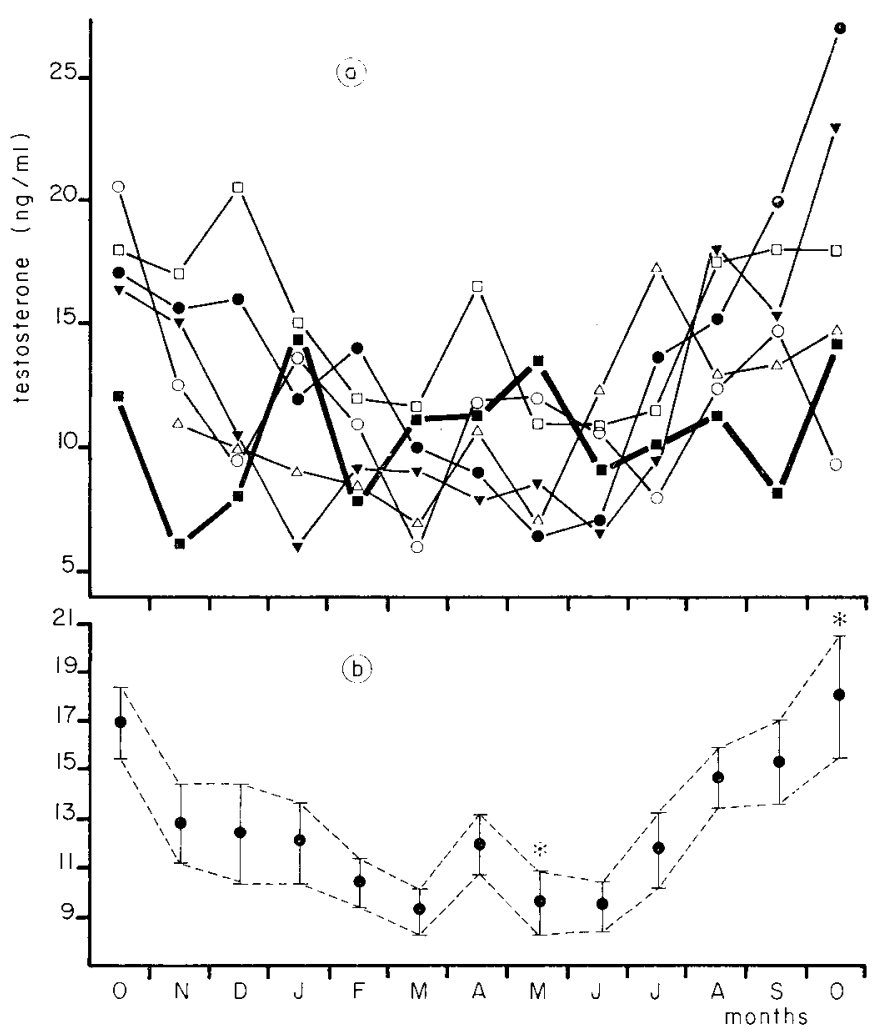

FIG. 1. - Individual (a) and mean \pm SE (b) testosterone levels of 6 males over a 1-year period.

* Significant difference, $\mathrm{P}<0.02$.

The plasma testosterone levels of 4 males, sampled at 1-hr intervals between $2: 30$ and 5:30 p. m. on one afternoon in March and in November the next year, are given in table 1. During the afternoons of these two months, the levels were relatively stable in all the animals. The mean hourly levels of the 4 macaques for each of these months were not significantly different. As in the previous experiment, the mean level of the male MN was the lowest ; it should be noted that this animal was the youngest in size and body weight. The overall mean level for all the samples was significantly higher 


\section{TABLE 1}

Plosma testosferone levels $(\mathrm{ng} / \mathrm{ml})$ in 4 males measured at 1-hr intervals on an afternoon in March and in November

\begin{tabular}{|c|c|c|c|c|c|c|}
\hline Animals & & $2: 30$ p. m. & $3: 30$ p. m. & 4:30 p. m. & 5:30 p. m. & $\bar{X} \pm S E$ \\
\hline 1 & $\begin{array}{l}\text { March } \ldots \ldots \ldots \\
\text { November......... }\end{array}$ & $\begin{array}{r}10.7 \\
9.3\end{array}$ & $\begin{array}{l}12.2 \\
11.4\end{array}$ & $\begin{array}{l}10.9 \\
13.4\end{array}$ & $\begin{array}{l}12.2 \\
11.8\end{array}$ & $\begin{array}{l}11.5 \pm 0.4 \\
11.5 \pm 0.8\end{array}$ \\
\hline N1 & $\begin{array}{l}\text { March } \ldots . . . \ldots \ldots \\
\text { November........ }\end{array}$ & $\begin{array}{r}7.8 \\
12.3\end{array}$ & $\begin{array}{r}10.8 \\
9.3\end{array}$ & $\begin{array}{r}9.7 \\
11.5\end{array}$ & $\begin{array}{l}10.5 \\
14.2\end{array}$ & $\begin{array}{r}9.7 \pm 0.7 \\
11.8 \pm 1.0\end{array}$ \\
\hline N2 & $\begin{array}{l}\text { March } \ldots . . . \ldots \ldots \\
\text { November........ }\end{array}$ & $\begin{array}{l}12.2 \\
15.6\end{array}$ & $\begin{array}{r}9.0 \\
12.4\end{array}$ & $\begin{array}{l}12.5 \\
11.5\end{array}$ & $\begin{array}{l}11.5 \\
11.2\end{array}$ & $\begin{array}{l}11.3 \pm 0.8 \\
12.7 \pm 1.0\end{array}$ \\
\hline$M N$ & $\begin{array}{l}\text { March } \ldots \ldots \ldots \ldots \\
\text { November........ }\end{array}$ & $\begin{array}{l}6.8 \\
8.2\end{array}$ & $\begin{array}{l}8.2 \\
9.3\end{array}$ & $\begin{array}{l}9.2 \\
7.5\end{array}$ & $\begin{array}{r}9.3 \\
12.3\end{array}$ & $\begin{array}{l}8.4 \pm 0.6 \\
9.3 \pm 1.0\end{array}$ \\
\hline$\overline{\bar{X}} \pm S E$ & $\begin{array}{l}\text { March } \ldots . . . \ldots \ldots \\
\text { November ........ }\end{array}$ & $\begin{array}{r}9.4 \pm 1.3 \\
11.3 \pm 1.6\end{array}$ & $\begin{array}{l}10.0 \pm 0.9 \\
10.6 \pm 0.8\end{array}$ & $\begin{array}{l}10.9 \pm 0.9 \\
11.0 \pm 1.2\end{array}$ & $\begin{array}{l}10.6 \pm 0.5 \\
12.3 \pm 0.6\end{array}$ & $\begin{array}{l}10.2 \pm 0.4 \\
11.3 \pm 0.5\end{array}$ \\
\hline
\end{tabular}

in November $(11.3 \pm 0.5 \mathrm{ng} / \mathrm{ml})$ than in March $(10.2 \pm 0.4 \mathrm{ng} / \mathrm{ml})$. The statistical analysis of these results shows that they do not differ significantly from those of the 6 animals for the same two months in the previous year.

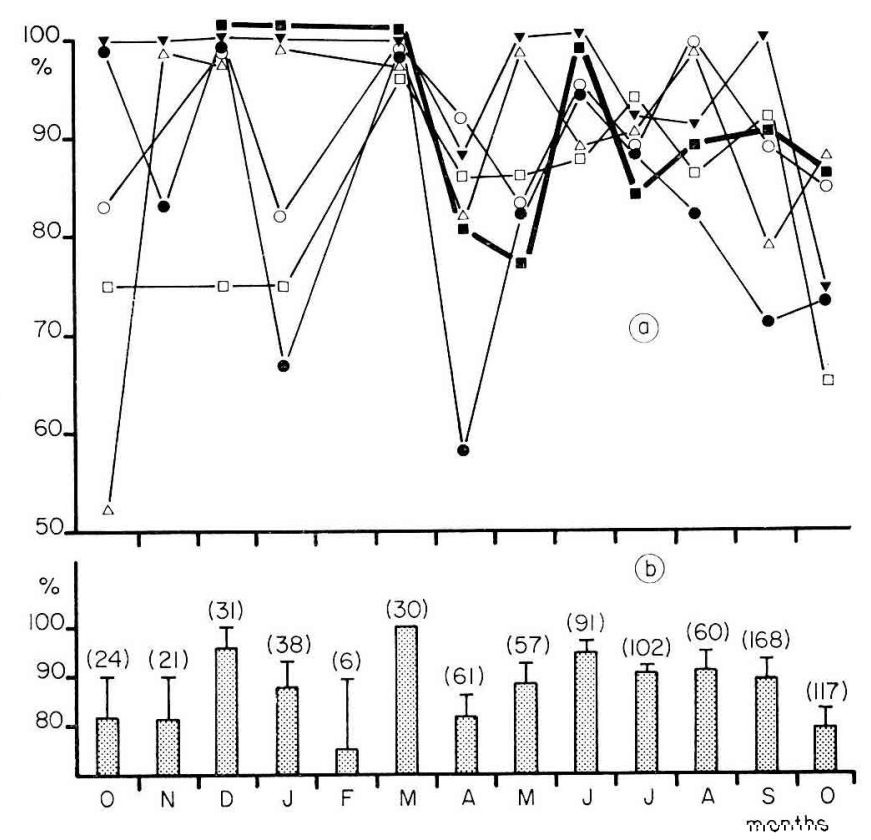

FIG. 2. - Individual (a) and mean \pm SE (b) ejaculatory rate of 6 males over a 1-year period. ( ) Total number of mating trials. 
The individual (a) or mean (b) ejaculatory ability of the males (fig. 2) did not follow an annual cycle concomitant with the plasma testosterone level.

We then divided the year into two periods according to the annual testosterone cycle : (i) August, September, October, November, December, January when the level was relatively high and (ii) February, March, April, May, June, July when the hormone level was low. We then correlated the monthly testosterone level of each animal with its monthly ejaculatory rate (fig. 3). In the first period (fig. 3a), we noted in all the animals that when the festosterone level was lower than $17 \mathrm{ng} / \mathrm{ml}$, the ejaculatory rate fluctuated, sometimes reaching 100 p. 100 ; above this critical level, the rate also fluctuated but did not reach 100 p. 100 . In the second period (fig. 3b), we observed the same phenomenon with a critical testosterone level of $11.5 \mathrm{ng} / \mathrm{ml}$. In other words, Macaca fascicularis males could ejaculate more or less rapidly all year long. Above a critical maximal festosterone level (which is higher when the annual testosterone level is relatively elevated than when it is low), the ejaculatory ability was somewhat depressed during the first $10 \mathrm{~min}$ after the female was presented.

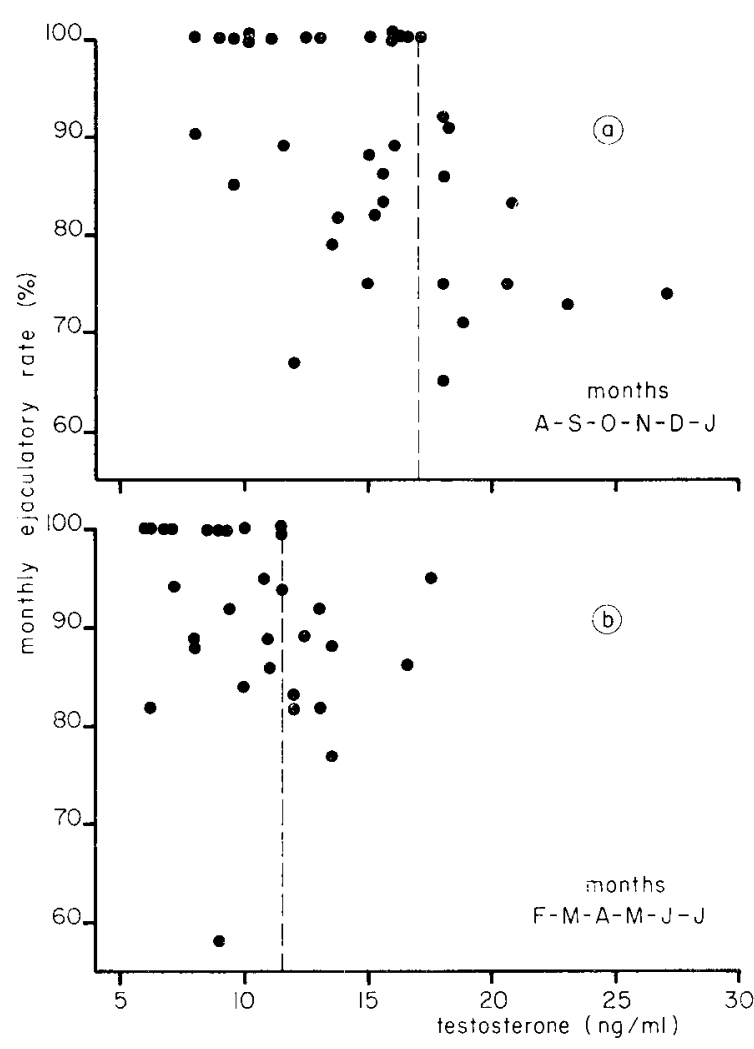

FIG. 3. - Relationship befween individual monthly testosterone level and individual monthly ejaculatory rafe. (a) First period when annual testosterone level is relatively high (August-September-October-November-December-January) ; (b) Second period when annual testosterone level is relatively low (February-March-April-May-June-July). 


\section{Discussion.}

Macaca mulatta has a circadian testosterone cycle with a low level from 8 to 9 a. $m$. and a high level from 9 to 10 p. m. (Plant and Michael, 1971 ; Goodman et al., 1974 ; Perachio et al., 1977). Reinberg ef al. (1975) observed that the plasma testosterone circadian acrophase in man varies as a function of the time of year so that regular sampling at the same time of day all year long is not valid for studying the annual cycle as they originally believed. The year-round circadian testosterone cycle has not yet been studied in the macaque. Assay of plasma testosterone sampled monthly in the afternoon in Macaca fascicularis shows an annual hormone cycle; therefore, this data must be accepted with reservations until further study.

As noted by Bernstein, Rose and Gordon (1974), Eaton and Resko (1974), Phoenix, Dixson and Resko (1977), the restraint technique of sampling macaque blood does not seem to stress the animals very much. Moreover, our males were trained to be sampled for more than one year before the present experiment started.

A comparison of the annual testosterone cycle in different species of male macaques and in man (table 2) shows that, except for Macaca arctoides and Macaca nemestrina, maximal simian levels always coincide with autumn, while the minimal levels coincide with spring in spite of different rearing environments. Serum testosterone levels in laboratory-housed Macaca arctoides living in a constant environment were found to vary significantly throughout the year with peak levels in June and low levels in September (Slob, Ooms and Vreeburg, 1979); this chronology differs from that of some other primates. The case of Macaca nemestrina is intriguing. The males of that species, although raised in an outside enclosure, did not exhibit seasonal testosterone cycles ; nevertheless, their values varied around the mean level (Bernstein ef al., 1978).

Moreover, a comparison of the testosterone levels in different macaque species and in man (table 2) reveals that the minimal as well as the maximal levels in Macaca fascicularis are higher than in other species.

As to copulatory behavior, Macaca fascicularis in our laboratory ejaculate regularly all year long (Dang, 1977) ; their ejaculatory ability measured by our present method does not follow an annual cycle concomitant with the plasma testosterone level. In laboratory-housed Macaca arctoides, Trollope and Blurton-Jones (1975) did not find any definite period of male sexual inactivity during the year; there was an annual serum testosterone cycle but the hormone levels did not correlate with ejaculatory behavior (Slob, Ooms and Vreeburg, 1979).

Our analysis indicates that once the blood testosterone level is between the minimum and the maximum, hormone level fluctuation no longer affects sexual ejaculatory behavior. Castration and supplementation experiments support this hypothesis. The testosterone level in the castrated male rhesus macaque is very low (Perachio et al., 1977), and reduced or abolished ejaculatory behavior is restored after testosterone injection, but a high dose of this hormone cannot increase the sexual level above that observed before castration (Resko and Phoenix, 1972 ; Phoenix, Slob and Goy, 1973 ; Michael and Wilson, 1974). Likewise, injecting an intact male rhesus macaque with testosterone does not enhance its sexual performance (Phoenix, Dixson and Resko, 1977). 
TABLE 2

Comparison of annual testosterone levels in man and macaque

\begin{tabular}{|c|c|c|c|c|}
\hline Simian primates & Living conditions & $\begin{array}{c}\text { Max. level } \\
(\mathrm{ng} / \mathrm{ml})\end{array}$ & $\begin{array}{c}\text { Min. level } \\
(\mathrm{ng} / \mathrm{ml})\end{array}$ & Authors \\
\hline Homo sapiens & in town & $\begin{array}{l}9.09 \pm 0.42 \\
\text { Oct.-Nov. } \\
7.62 \pm 2.16 \\
\text { July-Oct }\end{array}$ & $\begin{array}{l}6.40 \pm 0.51 \\
\text { April-May } \\
6.31 \pm 1.33 \\
\text { Jan.-April }\end{array}$ & $\begin{array}{c}\text { Reinberg and Lagoguey (1975) } \\
\text { Smals ef al. (1976) }\end{array}$ \\
\hline Macaca mulatta & 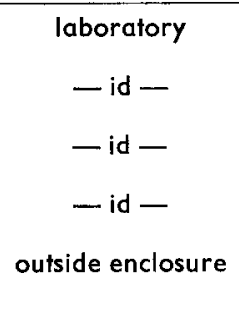 & $\begin{array}{c}11.50 \\
\text { Sept.-Oct. } \\
10.50 \\
\text { Sept.-Dec. } \\
11.50 \\
\text { July-Sept. } \\
15.5 \pm 2.0 \\
\text { Sept.-Dec. } \\
12.00 \\
\text { Oct.-Nov. }\end{array}$ & $\begin{array}{c}6.00 \\
\text { April-June } \\
5.50 \\
\text { March-June } \\
6.00 \\
\text { April-May } \\
5.0 \pm 0.5 \\
\text { April-June } \\
2.00 \\
\text { March-June }\end{array}$ & $\begin{array}{c}\text { Plant et al. (1974) } \\
\text { Michael and Bonsall (1977) } \\
\text { Beck and Wuttke (1979) } \\
\text { Wickings and Nieschlag (1980) } \\
\text { Gordon et al. (1976) }\end{array}$ \\
\hline Macaca nemestrina & outside enclosure & $\begin{array}{l}16.5 \\
\text { No seasonal } \\
\text { fluctuation }\end{array}$ & 9.0 & Bernstein ef al. (1978) \\
\hline Macaca arctoides & laboratory & $\begin{array}{l}14.77 \\
\text { June }\end{array}$ & $\begin{array}{r}\text { 6.67-7.15 } \\
\text { Aug.-Sept. }\end{array}$ & Slob ef al. (1979) \\
\hline Macaca fascicularis & laboratory & $\begin{array}{c}16.70 \pm 1.10 \\
\text { Sept.-Oct. }\end{array}$ & $\begin{array}{l}9.50 \pm 0.93 \\
\text { March-June }\end{array}$ & \\
\hline
\end{tabular}

Macaca fascicularis seems to have a given maximal testosterone level depending on the season ; above that level, the ejaculation rate may be depressed. It is interesting to correlate this result with those in the castrated male Macaca mulatta ; although injected with a daily constant dose $(2 \mathrm{mg})$ of testosterone proprionate throughout the year, that simian displayed seasonal ejaculatory activity with a peak in autumn (Michael and Wilson, 1975).

Our animals ejaculate all year long because the females have regular menstrual cycles and only preovulatory females are chosen for testing male sexual activity. A female rhesus given estrogen may stimulate the copulatory activity of males in sexual rest (Vandenbergh, 1969). We do not know if the constant ovulatory menstrual cycles are due to the permanent round-the-year sexual activity of our males, but copulation cannot initiate ovarian activity in the female rhesus in seasonal rest (Vandenbergh and Post, 1976).

Reçu en mai 1980.

Accepté en septembre 1980.

Acknowledgements. - This research was supported by the DGRST, CNRS (L. A. 220) and UER Biomédicale Paris. We are grateful to Professors A. Delmas, J. Hureau and C. Thibault for their encouragement and discussion. Special thanks are due to Mrs. Alice Daifuku for help in editing this manuscript and to G. Aphaecix, R. Baret and $M$. Carpentier for the animal care. 
Résumé. L'étude a porté sur 6 mâles Macaca fascicularis adultes, fertiles et sains, élevés au laboratoire. Le dosage radioimmunologique de la testostérone, dans le plasma obtenu à partir de prélèvements effectués dans l'après-midi, au début de chaque mois, sans anesthésie, a révélé un cycle annuel du taux de cette hormone avec un maximum $(16,7 \pm 1,1 \mathrm{ng} /$ $\mathrm{ml}$ ) en automne et un minimum $(9,5 \pm 0,9 \mathrm{ng} / \mathrm{ml})$ au printemps (fig. 1). L'activité éjaculatoire de ces animaux en présence des femelles aux 12-15e jours de leur cycle menstruel, observée pendant 10 minutes et mesurée par le rapport: nombre d'éjaculations/nombre d'épreuves, ne varie pas d'une façon cyclique au cours de l'année (fig. 2 ).

En comparant le cycle annuel du taux de testostérone chez le Macaque (Macaca mulatta, Macaca arcfoides, Macaca nemestrina, Macaca fascicularis) et chez l'Homme, nous avons observé chez ces simiens, excepté chez Macaca arctoides et Macaca nemestrina, que les taux maxima coïncident au même moment de l'année (automne), de même pour les taux minima (printemps) en dépit des différents environnements où ils vivent (tabl. 2).

Chez le Macaque, l'examen de l'activité éjaculatoire et du taux de testostérone plasmatique de l'animal entier au cours de l'année, comparés à ceux observés chez le castré (Resko et Phoenix, 1972 ; Phoenix ef al., 1973 ; Michael et Wilson, 1974, 1975) amène à penser qu'au-dessus d'un niveau minimum, la variation du taux de cette hormone n'affecte plus le comportement sexuel mâle, tout au moins en ce qui concerne l'activité éjaculatoire. De plus, au cours de cette étude, nous avons aperçu qu'au-dessus d'un taux maximum de testostérone, variable suivant la saison, on assisterait à une diminution de la rapidité à l'éjaculation (fig. 3).

\section{References}

ASO T., TOMINAGA T., OSHIMA K., MATSUBAYASHI K., 1977. Seasonal changes of plasma estradiol and progesterone in the japanese monkey (Macaca fuscata fuscata). Endocrinology, 3, 745-750.

BECK W., WUTTKE W., 1979. Annual rhythms of luteinizing hormone, follicle-stimulating hormone, prolactine and testosterone in the serum of male rhesus monkeys. J. Endocrinol., 83, 131-139.

BERNSTEIN I. S., GORDON T. P., ROSE R. M., PETERSON M. S., 1978. Influences of sexual and social stimuli upon circulating levels of testosterone in male Pigtail Macaque. Behav. Biol., 24, 400-404.

BERNSTEIN I. S., ROSE R. M., GORDON T. P., 1974. Behavioral and environmental events influencing primate testosterone levels. J. hum. Evol., 3, 517-525.

CONOWAY C. H., KOFORD C. B., 1964. Estrous cycles and mating behavior in a freeranging band of Rhesus Monkey. J. Mammal., 45, 577-588.

DANG D. C., 1977. Absence of seasonal variation in the length of the menstrual cycle and the fertility of the Crab-Eating Macaque (Macaca fascicularis) raised under natural daylight ratio. Ann. Biol. anim. Bioch. Biophys., 17, 1-7.

DANG D. C., MEUSY-DESSOLLE N., 1979. Testosterone levels in umbilical cord blood, materna! peripheral plasma and amniotic fluid of the Crab-Eating Monkey (Macaca fascicularis). Ann. Biol. anim. Bioch. Biophys., 12, 1307-1316.

DIXSON A. F., 1977. Observations on the displays, menstrual cycles and sexual behaviour of the "Black ape " of Celebes (Macaca nigra). J. Zool., Lond., 182, 63-84.

EATON G. G., 1972. Seasonal sexual behavior : intrauterine contraceptive devices in a confined troop of japanese Macaques. Horm. Behav., 3, 133-142.

EATON G. G., RESKO J. A., 1974. Plasma testosterone and male dominance in a japanese macaque (Macaca fuscata) troop compared with repeated measures of testosterone in laboratory males. Horm. Behav., 5, 251-259.

ESTRADA A., ESTRADA R., 1976. Birth and breeding cyclicity in an outdoor living Stumptail Macaque (Macaca arctoïdes) group. Primates, 17, 225-235.

GAUQUELIN M. F., 1968. Le cycle annuel de reproduction du macaque, (Macaca irus). Bull. Biol., 2 , 261-270. 
GOODMAN R. L., HOTCHKISS J., KARSCH F. J., KNOBIL E., 1974. Diurnal variations in serum testosterone concentration in the adult male Rhesus monkey. Biol. Reprod., 11, 624-630.

GORDON T. P., ROSE R. M. BERNSTEIN I. S., 1976. Seasonal rhythm in plasma testosterone levels in the rhesus monkey (Macaca mulatfa) : a three-year study. Horm. Behav., 7, 229-243.

HANBY J. P., ROBERTSON L. T., PHOENIX C. H., 1971. The sexual behavior of a confined troop of japanese macaques. Folia Primatol., 16, 123-143.

LANCASTER J. B., LEE R. B., 1965. The annual reproductive cycle in monkeys and apes, 486-515. In DEVORE I. Primate Behaviour, Holt, Rinehart \& Winston. New York.

MCROBERTS M. H., MCROBERTS B. R., 1966. The annual reproductive cycle of the barbary ape (Macaca sylvana) in Gibraltar. Am. J. Phys. Anthropol., 25, 299-304.

MICHAEL R. P., BONSALL R. W., 1977. A 3-year study of an annual rhythm in plasma androgen levels in male rhesus monkey (Macaca mulatta) in a constant laboratory environment. J. Reprod. Fert., 49, 129-131.

MICHAEL R. P., KEVERNE E. B., 1971. An annual rhythm in the sexual activity of the male rhesus monkey, Macaca rhesus, in the laboratory. J. Endocrinol. 41, 421-431.

MICHAEL R. P. WILSON M. I., 1974. Effects of castration and hormone replacement in fully adult male rhesus. Endocrinology, 5, 150-159.

MICHAEL R. P., WILSON M. I., 1975. Mating seasonality in castrated male rhesus monkeys. J. Reprod. Fert., 43, 325-328.

NEUVILLE M. K., 1968. Ecology and activity of Himalayan foothill rhesus monkeys (Macaca mulatfa). Ecology, 49, 111-123.

NOMURA T., OHSAWA N., 1975. The use and problems associated with non-human primates in the study of reproduction. VIth ICLA Symp. Thessaloniki.

PERACHIO A. A., ALEXANDER M., MARR L. D., COLLINS D. C., 1977. Diurnal variations of serum testosterone levels in intact and gonadectomized male and female rhesus monkeys. Steroids, 20, 21-33.

PHOENIX C. H., DIXSON A. F., RESKO J. A., 1977. Effects of ejaculation on the level of testosterone, cortisol and luteinizing hormone in peripheral plasma of rhesus monkeys. J. comp. Physiol., 91, 120-127.

PHOENIX C. H., SLOB A. K., GOY R. W., 1973. Effects of castration and replacement therapy on the sexual behavior of adult male rhesuses. J. comp. physiol. Psychol., 84, 472-481.

PLANT T. M., MICHAEL R. P., 1971. Diurnal variations in plasma testosterone levels of adult male rhesus monkeys. Acta Endocrinol. (Kbh.), Suppl. 155, 69.

PLANT T. M., ZUMPE D., SAULS M., MICHAEL R. P., 1974. An annual rhythm in plasma testosterone of adult male rhesus monkeys maintained in the laboratory. J. Endocrinol., 62, 403-404.

REINBERG A., LAGOGUEY M., CHAUFFOURNIER J.-M., CESSELIN F., 1975. Circannual and circadian rhythms in plasma testosterone in five healthy young parisian males. Acfa Endocrinol, 80, 732-743.

RESKO J. A., PHOENIX C. H., 1972. Sexual behavior and testosterone concentration in the plasma of rhesus monkey before and after castration. Endocrinology, 91, 499-503.

RIESEN J. W., MEYER R. K., WOLF R. C., 1971. The effect of season on occurence of ovulation in rhesus monkey. Biol. Reprod, 5, 111-114.

ROBINSON J. A., SCHEFFER G., EISELE S. C., GOY R. W., 1975. Effect of age and season on sexual behavior and plasma testosterone and dihydrotestosterone concentration of laboratoryhoused male rhesus monkeys (Macaca mulatia). Biol. Reprod., 13, 203-210.

SLOB A. K., OOMS M. P., VREEBURG J. T. M., 1979. Annual changes in serum testosterone in laboratory housed male stumptail macaques (Macaca arctoïdes). Biol. Reprod., 20, 981-984.

SMALS A. G. H., KLOPPENBORG P. W. C., BENRAAD Th. J., 1976. Circannual cycle in plasma testosterone levels in man. J. clin. Endocrinol. Metab., 42, 979-982.

TOKUDA K., 1962. A study on the sexual behavior in the japanese monkey troop. Primates, 3, 1-40. TROLLOPE J., BLURTON-JONES N. G., 1975. Aspects of reproduction and reproductive behaviour in Macaca arctoïdes. Primates, 16, 191-205.

VALERIO D. A., PALLOTA A. J., COURTNEY K. D., 1969. Experiences in large scale breeding of simians for medical experimentation. Ann. N. Y. Acad. Sci., 162, 282-296. 
VANDENBERGH J. C., 1969. Endocrine coordination in monkeys : male sexual response to the female. Physiol. Behav., 4, 261-264.

VANDENBERGH J. C., POST W., 1976. Endocrine coordination in rhesus monkey : female responses to the male. Physiol. Behav., 17, 969-984.

VANDENBERGH J. C., VESSEY S., 1968. Seasonal breeding of free ranging rhesus monkeys and related ecological factors. J. Reprod. Fert., 15, 71.

WICKINGS E. J., NIESCHLAG E., 1980. Seasonality in endocrine and exocrine testicular function of the adult Rhesus Monkey (Macaca mulatta) maintained in a controlled laboratory environment. Int. J. Androl., 3, 87-104. 